\title{
Growth and Metal Accumulation in Vetiver and two Sesbania Species on Lead/Zinc Mine Tailings*
}

\author{
Bing Yang ${ }^{1}$, Wensheng Shu ${ }^{1}$, Zhihong Ye ${ }^{2}$, Chongyu Lan ${ }^{1}$, and Minghong Wong ${ }^{2 *}$ \\ ${ }^{1}$ School of Life Science, Sun Yatsen (Zhongshan) University, Guangzhou, 510275, China \\ ${ }^{2}$ Institute for Natural Resources and Environmental Management, and Department of Biology, \\ Hong Kong Baptist University, Kowloon Tong, Hong Kong, China
}

\begin{abstract}
The lead $(\mathrm{Pb}) /$ zinc $(\mathrm{Zn})$ tailings contained high concentrations of heavy metals (total $\mathrm{Pb}, \mathrm{Zn}$, $\mathrm{Cu}$ and $\mathrm{Cd}$ concentrations 4164, 4377, 35 and $32 \mathrm{mg} \mathrm{kg}^{-1}$, respectively), and low contents of major nutrient elements (N, P, and $\mathrm{K}$ ) and organic matter. A field trial was conducted to compare growth performance, metal accumulation of Vetiver (Vetiveria zizanioides) and two legume species (Sesbania rostrata and Sesbania sesban) grown on the tailings amended with domestic refuse and/or fertilizer. It was revealed that domestic refuse alone and the combination of domestic refuse and artificial fertilizer significantly improved the survival rates and growth of $V$. zizanioides and two Sesbania species, especially the combination. However, artificial fertilizer alone did not improve both the survival rate and growth performance of the plants grown on tailings. Roots of these species accumulated similar levels of heavy metals, but the shoots of two Sesbania species accumulated higher (3-4 folds) concentrations of $\mathrm{Pb}$, $\mathrm{Zn}, \mathrm{Cu}$ and $\mathrm{Cd}$ than shoots of $V$. zizanioides. Most of the heavy metals in $V$. zizanioides were accumulated in roots, and the translocation of metals from roots to shoots was restricted. Intercropping of $V$. zizanioides and $S$. rostrata did not show any beneficial effect on individual plant species, in terms of height, biomass, survival rate, and metal accumulation, possibly due to the rather short experimental period of 5 months.
\end{abstract}

Key words: growth performance, intercropping, $\mathrm{Pb} / \mathrm{Zn}$ mine, Sesbania rostrata, Sesbania sesban, tailings amendment, Vetiveria zizanioides

Email contact: Wensheng Shu $<\underline{1 \text { s53@zsu.edu.cn }>}$

\section{TRODUCTION}

Exploitation of mineral resource has resulted in the destruction of vast amounts of land. This has caused very serious environmental problems, which have received much attention from most countries in the world, including China. Revegetation of metalliferous mine tailings is necessary for long-term stability of the land surface. A good vegetation cover is beneficial in the restoration of contaminated land and results in enhanced amenity values as well as prevention of surface soil erosion (Baker et al., 1994). However, adverse factors such as acidity, nutrient deficiencies, toxic heavy metal ions, and poor physical structure, and their interactions of most mine tailings inhibit plant establishment and growth on the tailings (Pichtel and Salt, 1998). The toxicity of heavy metals and deficiency of major nutrients are often the limiting factors for plant establishment on mine tailings, therefore, the success of reclamation schemes should overcome the two major problems (Bradshaw, 1987).

In general, amendments such as applications of organic materials (such as sewage sludge, domestic refuse) or inorganic fertilizer are necessary for establishment of plants on mine tailings. For long-terms remediation, metal tolerant species are commonly used for revegetation of mine tailings (Lan et al., 1997;

${ }^{*}$ This paper has been published on Chemosphere, 2003, 52:1593-1600 
Sahi et al., 1999), and herbaceous legumes can be used to as pioneer species solve the problem of nitrogen deficiencies in mining wastelands because of their $\mathrm{N}_{2}$-fixing ability (Archer et al., 1988).

The genus Sesbania consisting of about 500 species pantropically distributed, is placed in the family Leguminosae, sub-family Papilionoideae. The majority of Sesbania species are annuals, and some are relatively short-lived perennials. Because of the ability of Sesbania species to grow in heavy metal soils, withstand waterlogging, and tolerate soil salinity, they are often the preferred green manure crop for rice and wheat (Evans and Rotar, 1987). Sesbania rostrata, native to tropical West Africa, is an annual species which bears stem as well as root nodules associated with Azorhizobium caulinodans, a specialized fast-growing strain of Rhizobia which can fix nitrogen in its free-living form (Somasegaran and Hoben, 1994). The formation of stem nodules in S. rostrata is considered as an unusual feature of harboring root primordial being formed along the stem (Tomekpe et al., 1996). S. rostrata is possibly the most rapid nitrogen-fixing plant known as it can fix $270 \mathrm{~kg} \mathrm{~N} / \mathrm{ha}$ in 52 days (Manguiat et al., 1987; Yang et al., 1998). Our previous study also demonstrated that $S$. rostrata could successfully grow on $\mathrm{Pb} / \mathrm{Zn}$ mine tailings amended with domestic refuse or sewage sludge (Ye et al., 2001). Vetiver grass (Vetiveria zizanioides), due to its fast growth, strong root system, high biomass, has been used to rehabilitate coal and gold tailings and mining overburden related to the mining industry (Truong and Baker, 1996).

Intercropping (IC) is a practice which can improve the utilization of available resources and cause yield advantage and increase yield stability compared to sole cropping (SC). Yield advantages occur when intercrop components compete only partly for the same plant growth resources. It is important of difference in competitive ability for growth factors between intercrop components (Ofori and stern, 1987). Legumes have been important crop plants with benefit of including improved soil quality, and reduced weed occurrence (Chris and Christopher, 2000). Ideally, cultivars suitable for IC should enhance the complementary effects between species (Vandermeer, 1989).

The objectives of the present field trial conducted at Lechang $\mathrm{Pb} / \mathrm{Zn}$ mine tailings of Guangdong Province, southern China, were to: (i) compare the growth performance, heavy metal accumulation of $V$. zizanioides and two legume species, S. rostrata and S. sesban; (ii) evaluate the effects of domestic refuse and inorganic fertilizer amendment on the revegetation of $\mathrm{Pb} / \mathrm{Zn}$ mine tailings; and (iii) evaluate whether IC of $V$. zizanioides with $S$. rostrata on the growth and heavy metal accumulation of these species on $\mathrm{Pb} / \mathrm{Zn}$ mine tailings.

\section{ATERIALS AND METHODS}

\subsection{Study Site}

The Lechang $\mathrm{Pb} / \mathrm{Zn}$ Mine is located at about $4 \mathrm{~km}$ east of Lechang City in the northern part of Guangdong Province, PR China. The climate is subtropical and the annual rainfall is about $1,500 \mathrm{~mm}$. It is a conventional underground mining operation covering an area of $1.5 \mathrm{~km}^{2}$, and produces approximately $30,000 \mathrm{t}$ of tailings annually, with a dumping area of $60,000 \mathrm{~m}^{2}$ (Shu, 1997). The tailings pond studied had been abandoned for about a year; the tailings surface of the pond was dry and completely devoid of vegetation.

\section{Table 1 Experimental design for spot trial}

\begin{tabular}{cl}
\hline Treatment & \\
\hline A & Tailings (control) \\
B & Tailings amended with inorganic fertilizer \\
C & Tailings amended with domestic refuse \\
D & Tailings amended with domestic refuse and inorganic fertilizer \\
\hline
\end{tabular}

*inorganic fertilizer (15\%N: 15\%P: 15\%K): $150 \mathrm{~kg} / \mathrm{ha}$; \#domestic refuse: $37.5 \mathrm{t} / \mathrm{ha}$ 


\subsection{Plant Growth Experiment}

A portion of the tailings pond was tilled to a depth of $20 \mathrm{~cm}$, and defended with wire netting to prevent tested plants from animals. A ditch of $30 \mathrm{~cm} \_30 \mathrm{~cm}$ was constructed outside the wire netting for drainage and separated the experiment area from surroundings. Sixteen plots $\left(2 \mathrm{~m}{ }_{-} 4 \mathrm{~m}\right)$ were set up within this area, and each plot was further divided into four subplots $\left(1 \mathrm{~m}{ }_{-} 2 \mathrm{~m}\right)$, with each subplot planted with $V$. zizanioides, $S$. sesban, or $S$. rostrata as SC respectively, or $V$. zizanioides and $S$. rostrata as mixed IC using a replacement design (50:50), at the rate of 32 individual plants per square meter. There were four treatments with four replicates each (Table 1). Healthy seedlings of $V$. zizanioides (about $20 \mathrm{~cm}$ in height), $S$. rostrata and $S$. sesban (about $10 \mathrm{~cm}$ in height) were collected from Guangzhou and transplanted to the experiment plots. Before planting, the seedlings of $S$. rostrata and $S$. sesban were soaked with theirs inoculants (isolated from the root nodules A.caulinodans and Sesbania caulinodans), respectively. After planting, treatments $\mathrm{B}$ and $\mathrm{D}$ received their first inorganic fertilization $(\mathrm{N}: \mathrm{P}$ : $\mathrm{K}=15: 15: 15$ ) at a rate of $150 \mathrm{~kg} / \mathrm{ha}$ monthly, treatment $\mathrm{A}$ and $\mathrm{C}$ were remained still. All the plots were watered daily, except for rainy days, at the first two months to improve the survival rate of plants. The survival rate and height of each species was recorded shortly before harvest, after a growth period of 20 weeks.

\subsection{Chemical Analysis}

Tailings samples were excavated from the tailings pond $(0-20 \mathrm{~cm})$ before the field trial in March 2001. Domestic refuse samples were collected from a nearby landfill which has been abandoned for about a year. All samples were air-dried and sieved through a 2-mm mesh and mixed well, for the following parameters were determined: $\mathrm{pH}$, electric conductivity (EC), water soluble $\mathrm{N}, \mathrm{P}, \mathrm{K}$ (solid: distilled water=1:2 w/v); total organic carbon $\left(\mathrm{H}_{2} \mathrm{SO}_{4}+\mathrm{KCrO}_{4}\right)$, total nitrogen $(\mathrm{N})$ (indophenol-blue method), total phosphate $(\mathrm{P})$ (molybdenum blue method), total $\mathrm{Zn}, \mathrm{Pb}, \mathrm{Cd}, \mathrm{Cu}$, and $\mathrm{K}$ (digested with conc. $\mathrm{HNO}_{3}$, and conc. $\left.\mathrm{HClO}_{4}=5: 1\right)$ and extractable $\mathrm{Zn}, \mathrm{Pb}, \mathrm{Cd}$, and $\mathrm{Cu}$ extracted by diethylene triaminepentaacetic acid (DTPA), by atomic absorption spectrometry, AAS) (Page et al., 1982).

\subsection{Plant Samples}

After a growth period of 20 weeks, shoots of the plants were clipped at $5 \mathrm{~mm}$ above ground, and roots were excavated as completely as possible to determine number of nodules for Legumes species. Plant materials were washed with distilled water, oven-dried (80_) to constant weight to determine dry weight, and then milled, divided into shoot and root portion, and passed through a $2 \mathrm{~mm}$ sieve. Approximately $0.5 \mathrm{~g}$ milled plant material was placed into a $100 \mathrm{ml}$ digesting tube, and then digested at 180 _ with $5 \mathrm{ml} 16 \mathrm{M} \mathrm{HNO}_{3}$ and $1 \mathrm{ml} 12 \mathrm{M} \mathrm{HClO}_{4}$, until the samples were completely clear. The concentrations of $\mathrm{Zn}, \mathrm{Pb}, \mathrm{Cu}$, and $\mathrm{Cd}$ in the digestates were determined by AAS (Allen, 1989).

\subsection{Statistical Analysis}

The data were analyzed using a SPSS statistical package by one-way analysis of variance (ANOVA) to compare the means of different treatments. Where significant $F$ values were obtained, differences between individual means were tested using LSD tests at 0.05 significance level.

\section{RESULTS}

\subsection{General Physio-chemical Properties of Tailings and Domestic Refuse}

The general properties of tailings and domestic refuse are presented in Table 2. The tailings were slightly alkaline $(\mathrm{pH}=8.55)$, with an $\mathrm{EC}$ value of $0.41 \mathrm{dS} \mathrm{m}^{-1}$, while the domestic refuse was near neutral 
$(\mathrm{Ph}=7.56)$, with an EC value of $1.05 \mathrm{dS} \mathrm{m}^{-1}$. The domestic refuse contained high levels of total $\mathrm{N}, \mathrm{P}$, and $\mathrm{K}$, which were about 40,4 and 4 times respectively higher than those in the tailings. In terms of heavy metals, concentrations of the total and DTPA-extractable $\mathrm{Zn}, \mathrm{Pb}$ and $\mathrm{Cd}$ in the tailings were significantly higher, while total and DTPA-extractable $\mathrm{Cu}$ significantly lower than those in domestic refuse.

Table 2 General physio-chemical properties of tailings and domestic refuse (Mean $\pm \mathrm{SE}, \mathbf{n}=\mathbf{5}$ )

\begin{tabular}{|c|c|c|c|c|c|}
\hline & Parameters & \multicolumn{2}{|l|}{ Units } & Tailings & Domestic refuse \\
\hline & $\mathrm{pH}$ & & 012 & 8.55 & $7.56 \pm 0.07$ \\
\hline & $\mathrm{EC}$ & $\mathrm{dS} \mathrm{m}^{-1}$ & 007 & 0.41 & $1.05 \pm 0.06$ \\
\hline & Organic Carbon & $\%$ & 013 & 1.4 & $3.6 \pm 0.15$ \\
\hline & Total & $\mathrm{mg} \mathrm{kg}^{-1}$ & 589 & 52.3 & $2356 \pm 212$ \\
\hline & Water-soluble & $\mathrm{mg} \mathrm{kg}^{-1}$ & 1 & $0.11 \pm 0$. & $0.18 \pm 0.002$ \\
\hline & Total & $\mathrm{mg} \mathrm{kg}^{-1}$ & 30.0 & 550 & $2245 \pm 178$ \\
\hline & Water-soluble & $\mathrm{mg} \mathrm{kg}^{-1}$ & 0.01 & 0.07 & $0.52 \pm 0.04$ \\
\hline & Total & $\mathrm{mg} \mathrm{kg}^{-1}$ & 192 & 1525 & $6865 \pm 486$ \\
\hline & Water-soluble & $\mathrm{mg} \mathrm{kg}^{-1}$ & 0.03 & 0.25 & $2956 \pm 134$ \\
\hline & Total & $\mathrm{mg} \mathrm{kg}^{-1}$ & 00 & $4377 \pm 1$ & $1080 \pm 177$ \\
\hline $\mathrm{n}$ & $\begin{array}{l}\text { DTPA- } \\
\text { extractable }\end{array}$ & $\mathrm{mg} \mathrm{kg}^{-1}$ & & $187 \pm 4$ & $73 \pm 4.95$ \\
\hline & Total & $\mathrm{mg} \mathrm{kg}^{-1}$ & 554 & 4164 & $297 \pm 50.1$ \\
\hline $\mathrm{b}$ & $\begin{array}{l}\text { DTPA- } \\
\text { extractable }\end{array}$ & $\mathrm{mg} \mathrm{kg}^{-1}$ & & $331 \pm 5$ & $62 \pm 5.73$ \\
\hline & Total & $\mathrm{mg} \mathrm{kg}^{-1}$ & 4.44 & 35 & $48 \pm 3.03$ \\
\hline $\mathrm{u}$ & $\begin{array}{l}\text { DTPA- } \\
\text { extractable }\end{array}$ & $\mathrm{mg} \mathrm{kg}^{-1}$ & 0.17 & 2.6 & $5.5 \pm 1.41$ \\
\hline & C $\quad$ Total & $\mathrm{mg} \mathrm{kg}^{-1}$ & 3.12 & 32 & $10 \pm 1.14$ \\
\hline d & $\begin{array}{l}\text { DTPA- } \\
\text { extractable }\end{array}$ & $m g \mathrm{~kg}^{-1}$ & 0.18 & 0.77 & $0.32 \pm 0.02$ \\
\hline
\end{tabular}

\subsection{Growth Performance of the Three Plant Species}

The growth performance (survival rate, height, and biomass) of V. zizanioides and two Sesbania species are listed in Table 3. In general, the plants grown on treatment $\mathrm{D}$ had the best growth performance. The height and biomass of the three plants were in the descending order of $\mathrm{D}>\mathrm{C}>\mathrm{B}>\mathrm{A}$. $S$. rostrata grown under the treatment $\mathrm{D}$ had the highest biomass $\left(1379 \mathrm{~g} \mathrm{~m}^{-2}\right)$ and height $(216 \mathrm{~cm})$, which were significantly higher than those of $V$. zizanioides $\left(1111 \mathrm{~g} \mathrm{~m}^{-2}\right.$ and $174 \mathrm{~cm}$, respectively) and $S$. sesban ( $455 \mathrm{~g} \mathrm{~m}^{-2}$ and $155 \mathrm{~cm}$, respectively) growing under the same treatment.

Table 3 Survival rate $(\%)$, height $(\mathrm{cm})$, and biomass ( $\mathrm{g}$ dry weight $\mathrm{m}^{-2}$ ) (Mean $\left.\pm \mathrm{SE}, \mathrm{n}=4\right)$ of Vetiveria zizanioides, Sesbania rostrata, and $S$. sesban grown on Lechang $\mathrm{Pb} / \mathrm{Zn}$ mine tailings under different treatments for a period of 20 weeks 


\begin{tabular}{ccccc}
\hline & Treatment & V.zizanioides & S. rostrata & S. sesban \\
\hline Survival rate & A & $90 \pm 1.2 \mathrm{a}^{*}$-a\# & $18 \pm 1.4 \mathrm{c}-\mathrm{b}$ & $6.3 \pm 1.6 \mathrm{~b}-\mathrm{c}$ \\
& B & $90 \pm 3.7 \mathrm{a}-\mathrm{a}$ & $27 \pm 4.5 \mathrm{c}-\mathrm{b}$ & $7.0 \pm 0.59 \mathrm{~b}-\mathrm{c}$ \\
& C & $95 \pm 3.3 \mathrm{a}-\mathrm{a}$ & $59 \pm 5.1 \mathrm{~b}-\mathrm{b}$ & $85.2 \pm 5.1 \mathrm{a}-\mathrm{a}$ \\
& D & $93 \pm 1.2 \mathrm{a}-\mathrm{a}$ & $86 \pm 2.3 \mathrm{a}-\mathrm{a}$ & $87 \pm 3.7 \mathrm{a}-\mathrm{a}$ \\
\hline Height & A & $91 \pm 1.2 \mathrm{~d}-\mathrm{a}$ & $12 \pm 1.4 \mathrm{~b}-\mathrm{bc}$ & $14 \pm 0.66 \mathrm{~d}-\mathrm{b}$ \\
& B & $113 \pm 1.9 \mathrm{c}-\mathrm{a}$ & $13 \pm 0.37 \mathrm{~b}-\mathrm{c}$ & $23 \pm 0.58 \mathrm{c}-\mathrm{b}$ \\
& C & $154 \pm 2.0 \mathrm{~b}-\mathrm{bc}$ & $210 \pm 6.0 \mathrm{a}-\mathrm{a}$ & $103 \pm 5.0 \mathrm{~b}-\mathrm{d}$ \\
& D & $174 \pm 3.5 \mathrm{a}-\mathrm{b}$ & $216 \pm 19 \mathrm{a}-\mathrm{a}$ & $155 \pm 2.6 \mathrm{a}-\mathrm{b}$ \\
\hline Biomass & A & $213 \pm 5 \mathrm{c}-\mathrm{a}$ & $29 \pm 2 \mathrm{c}-\mathrm{b}$ & $26 \pm 2 \mathrm{c}-\mathrm{b}$ \\
& B & $331 \pm 18 \mathrm{c}-\mathrm{a}$ & $57 \pm 2 \mathrm{c}-\mathrm{b}$ & $40 \pm 1 \mathrm{c}-\mathrm{b}$ \\
& C & $782 \pm 84 \mathrm{~b}-\mathrm{a}$ & $891 \pm 44 \mathrm{~b}-\mathrm{a}$ & $169 \pm 10 \mathrm{~b}-\mathrm{b}$ \\
& D & $1111 \pm 144 \mathrm{a}-\mathrm{a}$ & $1379 \pm 42 \mathrm{a}-\mathrm{a}$ & $455 \pm 25 \mathrm{a}-\mathrm{b}$ \\
\hline
\end{tabular}

Refer to Table 1 for the explanation of treatment. Data with different letters $(*)$ in the same column, or (\#) in the same row indicate a significant difference at 5\% level according to LSD test

Survival rates (\%) of $V$. zizanioides were similar in the all treatments, but survival rates of $S$. rostrata and $S$. sesban grown in treatments $\mathrm{C}$ and D were significantly higher than their counterparts grown in treatments A and B. S. sesban seedlings grown in treatments A and B were almost dead at the end of experiment and with extremely low survival rates $(6.25 \%$ and $7.03 \%$, respectively) (Table 3$)$.

There were no significant differences in growth performance (biomass, height and survival rate) between the SC S. rostrata ( $V$. zizanioides) and IC $S$. rostrata ( $V$. zizanioides) under the same treatment (data not shown).

\subsection{Nodulation of Two Sesbania Species}

The biomass and number of nodules of two Sesbania species grown in D subplots were significantly higher than in A and B subplots. The biomass and nodule number of S. rostrata were significantly higher than those of $S$. sesban under the same treatment (Table 4). There were no significant difference in biomass and number of nodules between SC S. rostrata and IC S. rostrata under the same treatment (data not shown).

Table 4 Number (/plant) and biomass (g dry weight/plant) of root nodulation per plant of Sesbania rostrata and $S$. sesban, grown on tailings under different treatments

\begin{tabular}{cccc}
\hline & Treatment & S. rostrata & S. sesban \\
\hline Number of & A & $12 \pm 2 \mathrm{~d}^{*} \mathrm{a}$ a & $7 \pm 1 \mathrm{~d}-\mathrm{b}$ \\
nodules & B & $54 \pm 18 \mathrm{c}-\mathrm{a}$ & $30 \pm 9 \mathrm{c}-\mathrm{b}$ \\
& C & $193 \pm 19 \mathrm{~b}-\mathrm{a}$ & $143 \pm 12 \mathrm{~b}-\mathrm{b}$ \\
Biomass of & D & $420 \pm 28 \mathrm{a}-\mathrm{a}$ & $224 \pm 20 \mathrm{a}-\mathrm{b}$ \\
nodules & A & $0.06 \pm 0.02 \mathrm{c}-\mathrm{a}$ & $0.04 \pm 0.01 \mathrm{~d}-\mathrm{a}$ \\
& $\mathrm{B}$ & $0.30 \pm 0.14 \mathrm{~b}-\mathrm{a}$ & $0.18 \pm 0.08 \mathrm{c}-\mathrm{b}$ \\
& C & $0.64 \pm 0.04 \mathrm{~b}-\mathrm{a}$ & $0.41 \pm 0.04 \mathrm{~b}-\mathrm{a}$ \\
& D & $1.22 \pm 0.12 \mathrm{a}-\mathrm{a}$ & $0.59 \pm 0.08 \mathrm{a}-\mathrm{b}$ \\
\hline
\end{tabular}

Refer to Table 1 for the explanation of treatments. Data with different letters $(*)$ in the same column, or (\#) in the same row indicate a significant difference at $5 \%$ level according to LSD test.

\subsection{Metal ( $\mathrm{Zn}, \mathrm{Pb}, \mathrm{Cu}$, and $\mathrm{Cd})$ Concentrations in Plant Tissues}

The concentrations of $\mathrm{Zn}, \mathrm{Pb}, \mathrm{Cu}$, and $\mathrm{Cd}$ in tissues of $V$. zizanioides and two Sesbania species are presented in Table 5. Metal concentrations exhibited similar trends among species, tissues and treatments. In general, plants accumulated high concentrations of $\mathrm{Pb}$ and $\mathrm{Zn}$, and low concentrations of $\mathrm{Cu}$ and $\mathrm{Cd}$; and roots always accumulated significantly higher heavy metals than shoots. The metal concentrations in same tissues (shoot or root) of plants under different treatments were generally in the descending order of $\mathrm{D} \approx \mathrm{C}>\mathrm{B} \approx \mathrm{A}$. However, the two Sesbania species under different treatments accumulated similar 
concentrations of $\mathrm{Zn}(P>0.05)$. Among the three species, $V$. zizanioides always accumulated the lowest concentrations of $\mathrm{Pb}, \mathrm{Zn}, \mathrm{Cu}$ and $\mathrm{Cd}$ (Table 5). The metal accumulations in IC V. zizanioides and $S$. rostrata were similar with those of their counterparts (SC) grown under the same treatment (data not shown).

\section{DISCUSSION}

Many factors such as poor physical structure, low water and nutrient holding capacity, deficiency of major nutrients (N, P, K), acidity and alkaline, water supply, toxic materials, salinity, stability, surface temperature are known to affect plant establishment on mine tailings (Bradshaw and Chadwick, 1980). Results presented in Table 2 indicated that Lechang $\mathrm{Pb} / \mathrm{Zn}$ mine tailings contained high levels of total and DTPA-extractable $\mathrm{Pb}$ and $\mathrm{Zn}$, and low levels of major nutrients $(\mathrm{N}, \mathrm{P}, \mathrm{K})$ and organic materials. The total and extractable concentrations of $\mathrm{Pb}$ and $\mathrm{Zn}$ greatly exceeded the background values of normal soil $(\mathrm{Pb}$ 22.50, Zn $\left.29.00 \mathrm{mg} \mathrm{kg}^{-1}\right)(\mathrm{Xu}$ and Liu, 1996), and nutrient contents and organic matter were much lower than those of normal soil (N, P, K, and organic matter 1240, 870, 21600, and $23500 \mathrm{mg} \mathrm{kg}^{-1}$, respectively) (Liu, 1993), although $\mathrm{pH}$ and $\mathrm{EC}$ values were in the normal range for plant growth. Therefore, the toxic levels of heavy metals, deficiency of nutrients $(\mathrm{N}, \mathrm{P}, \mathrm{K})$ and low organic matter in the tailings might be the major constraints for plant establishment on Lechang $\mathrm{Pb} / \mathrm{Zn}$ mine tailings pond. Our previous study also demonstrated that phyto-toxicity of heavy metals and extreme infertility of the Fankou $\mathrm{Pb} / \mathrm{Zn}$ mine tailings in northern Guangdong Province were the major limiting factors for plant growth (Lan et al., 1998; Shu et al., 1997). Therefore, application of inorganic fertilizer or organic materials is necessary for successful revegetation of these tailings. Results in the present experiment demonstrated that domestic refuse and the combination of inorganic fertilizer and domestic refuse greatly enhanced the growth of $V$. zizanioides, S. rostrata, and S. sesban and the nodulation of the two Sesbania species on Lechang $\mathrm{Pb} / \mathrm{Zn}$ mine tailings, especially the combination. On the contrary, using inorganic fertilizer alone could not effectively improve plant growth on the tailings (Table 3). A number of studies showed that domestic refuse resulted in successful revegetation of mine spoils (Ye et al., 1999, 2000). Besides having high level of NPK, domestic refuse could also improve the poor physical properties and microbial activities of the tailings. Organic materials of domestic refuse could also reduce heavy metal toxicity to plants by complexing metals (Wong and Lau, 1985). There has been a long history in using domestic refuse as soil amendment in rural areas of China. However, due to the increased use of artificial fertilizer in recent years, domestic refuse has been disposed of in rural areas and cities without any treatment, which resulted in serious environmental problems (Jiang, 2000). The application of domestic refuse for revegetating derelict land may not only provide a cost-effective method for land rehabilitation, but also provide an alternative for refuse disposal.

It was commonly known that $V$. zizanioides tolerates wide range of $\mathrm{pH}$, salinity, sodicity, acidity and heavy metals such as $\mathrm{As}, \mathrm{Cd}, \mathrm{Cu}, \mathrm{Pb}$, and $\mathrm{Zn}$ (Kantawanichkul et al., 1996; Xia and Shu, 2001). In Australia, $V$. zizanioides has been successfully used to stabilize mining overburden, coal and gold mine tailings (Truong and Baker, 1996). The present results also showed that $V$. zizanioides has better growth performance (survival rate, height, and biomass) than the two legume species under the same treatment (Table 3). Accumulation and distribution of heavy metals in plant tissues are important aspects to evaluate the role of plant in remediation of metalliferous soils (Friedland, 1989). In terms of stabilizing metal contaminated sites, a lower metal concentration in shoot is preferred, in order to prevent metal from entering the ecosystem through food chain (Pichtel et al., 2000; Taylor et al., 2001). Among the three species studied, the shoot of $\mathrm{V}$. zizanioides accumulated the least concentrations of $\mathrm{Pb}, \mathrm{Zn}, \mathrm{Cu}$, and $\mathrm{Cd}$ 
(Table 5), and is therefore, more suitable for revegetation of mine tailings. Similar results were also observed in our previous study of growth and accumulation of heavy metals in four grasses grown on $\mathrm{Pb} / \mathrm{Zn}$ mine tailings (Shu et al., 2002). The restriction of metal translocation from root to shoot in $V$. zizanioides might be one of its metal tolerance strategies (Shu et al., 2002). All these evidences suggested that $V$. zizanioides has higher tolerance to metals (e.g. $\mathrm{Pb}$ and $\mathrm{Zn}$ ) than the two legume species. In addition, $V$. zizanioides also possess an extensive root system (the maximum diameter of root scale and height $30,70 \mathrm{~cm}$, respectively) to stabilize tailings particles and avoid erosion.

Although previous studies showed that Sesbania was able to grow on tin (Sn) (Radziah and Shamsuddin, 1990) and complete its life cycle and produced seeds on $\mathrm{Pb} / \mathrm{Zn}$ tailings within about nine month (Yang et al., 1997), which suggested that S. rostrata might possess a certain degree of heavy metal tolerance. The results presented that $S$. rostrata and $S$. sesban grown in $\mathrm{C}$ and D subplots had significantly better growth performance than in A and B subplots. The results also showed that the biomass of $S$. rostrata was higher than that of $V$. zizanioides when grown in the same $\mathrm{C}$ and $\mathrm{D}$ subplots (Table3). Root nodules of $S$. rostrata might also contribute to $\mathrm{N}$ accumulation in the substrate. Therefore, this plant could be used as a pioneer species to improve edaphic conditions of mine tailings. However, organic amendment such as the use of domestic refuse is necessary for enhancing plant growth on tailings. Although the stem nodulation of the species was emphasized (Tomekpe et al., 1996; Ye et al., 2001), where nitrogen application stimulated nodulation and $\mathrm{N}_{2}$ fixation in stems of $S$. rostrata, also heavy metals tend to reduce the nodulation rate of S.rostrata, especially at low $\mathrm{pH}$ (Ibekwe et al., 1995). No stem nodule was observed during the present study. Failure of nodulation on stem of S. rostrata growing on tailings might due to the degradation of bacteria strain or the stem nodule bacteria was more susceptible by high metal toxicities.

IC of grasses and legumes are recommended in revegetation of wasteland in order to ensure a longterm stability of vegetation, due to contribution of $\mathrm{N}$ by legume species (Bradshaw and Chadwick, 1980). However, present results did not show any competitive and beneficial effects on growth performance of $S$. rostrata and $V$. zizanioides growing in the same subplot. This may be due to the relatively short experimental period (20 weeks) and the beneficial effect of legume species was not clearly manifested. Therefore, the long-term role of legume species in IC system for mine tailings revegetation needed further investigation. The effects of decomposition of S. rostata on the growth of grasses on the tailings are being studied.

Table 5 Concentrations (mean $\pm \mathrm{se}, \mathrm{n}=4, \mathrm{mg} \mathrm{kg}^{-1}$ ) of $\mathrm{Zn}, \mathrm{Pb}, \mathrm{Cu}$, and $\mathrm{Cd}$ in plants of $\mathrm{V}$. zizanioides, Sesbania rostrata, and $S$. sesban grown on tailings under different treatments

\begin{tabular}{cccccccc}
\hline & \multicolumn{2}{c}{ V. zizanioides } & \multicolumn{2}{c}{ S. rostrata } & \multicolumn{2}{c}{ S. sesban } \\
\hline & Treatment & Shoot & Root & Shoot & Root & Shoot & Root \\
\hline $\mathrm{Zn}$ & $\mathrm{A}$ & $57 \pm 14 \mathrm{ab}$ & $1162 \pm 620 \mathrm{a}$ & $216 \pm 72 \mathrm{a}$ & $605 \pm 235 \mathrm{a}$ & $209 \pm 30 \mathrm{a}$ & $383 \pm 119 \mathrm{a}$ \\
& $\mathrm{B}$ & $64 \pm 19 \mathrm{a}$ & $911 \pm 324 \mathrm{a}$ & $186 \pm 66 \mathrm{a}$ & $374 \pm 55 \mathrm{a}$ & $225 \pm 15 \mathrm{a}$ & $348 \pm 154 \mathrm{a}$ \\
& $\mathrm{C}$ & $37 \pm 4.6 \mathrm{c}$ & $351 \pm 44 \mathrm{~b}$ & $192 \pm 58 \mathrm{a}$ & $562 \pm 125 \mathrm{a}$ & $237 \pm 83 \mathrm{a}$ & $309 \pm 94 \mathrm{a}$ \\
& $\mathrm{D}$ & $43 \pm 5.9 \mathrm{bc}$ & $316 \pm 56 \mathrm{~b}$ & $157 \pm 69 \mathrm{a}$ & $448 \pm 148 \mathrm{a}$ & $158 \pm 57 \mathrm{a}$ & $505 \pm 199 \mathrm{a}$ \\
$\mathrm{Pb}$ & $\mathrm{A}$ & $18 \pm 4.0 \mathrm{a}$ & $720 \pm 213 \mathrm{a}$ & $33 \pm 14 \mathrm{a} \mathrm{b}$ & $227 \pm 122 \mathrm{a}$ & $13 \pm 2.3 \mathrm{~b}$ & $100 \pm 25 \mathrm{ab}$ \\
& $\mathrm{B}$ & $13 \pm 5.4 \mathrm{ab}$ & $456 \pm 54 \mathrm{~b}$ & $46 \pm 17 \mathrm{a}$ & $156 \pm 19 \mathrm{a}$ & $27 \pm 9.1 \mathrm{a}$ & $109 \pm 53 \mathrm{ab}$ \\
& $\mathrm{C}$ & $7.9 \pm 1.8 \mathrm{~b}$ & $146 \pm 28 \mathrm{c}$ & $23 \pm 13 \mathrm{~b}$ & $217 \pm 87 \mathrm{a}$ & $14 \pm 1.9 \mathrm{~b}$ & $91 \pm 32 \mathrm{~b}$ \\
& $\mathrm{D}$ & $8.0 \pm 2.9 \mathrm{~b}$ & $141 \pm 31 \mathrm{c}$ & $17 \pm 4.1 \mathrm{~b}$ & $197 \pm 25 \mathrm{a}$ & $12 \pm 5.5 \mathrm{~b}$ & $158 \pm 51 \mathrm{a}$ \\
$\mathrm{Cu}$ & $\mathrm{A}$ & $3.7 \pm 1.9 \mathrm{a}$ & $58.7 \pm 17.7 \mathrm{a}$ & $11 \pm 4.3 \mathrm{ab}$ & $30 \pm 9.8 \mathrm{a}$ & $12.4 \pm 1.1 \mathrm{~b}$ & $57 \pm 17 \mathrm{ab}$ \\
& $\mathrm{B}$ & $4.7 \pm 1.42 \mathrm{a}$ & $58.1 \pm 9.51 \mathrm{a}$ & $12 \pm 0.33 \mathrm{a}$ & $29 \pm 3.9 \mathrm{a}$ & $16 \pm 1.0 \mathrm{a}$ & $47 \pm 4.4 \mathrm{~b}$ \\
& $\mathrm{C}$ & $5.0 \pm 2.0 \mathrm{a}$ & $30 \pm 3.9 \mathrm{~b}$ & $7.9 \pm 1.8 \mathrm{~b}$ & $36 \pm 7.9 \mathrm{a}$ & $10 \pm 2.5 \mathrm{bc}$ & $68 \pm 16 \mathrm{a}$ \\
& $\mathrm{D}$ & $7.90 \pm 4.62 \mathrm{a}$ & $28.2 \pm 3.14 \mathrm{~b}$ & $8.2 \pm 1.0 \mathrm{~b}$ & $39 \pm 14 \mathrm{a}$ & $8.3 \pm 3.2 \mathrm{c}$ & $57 \pm 16 \mathrm{ab}$ \\
\hline
\end{tabular}




\begin{tabular}{llllllll}
\hline Cd & A & n. d. & $4.98 \pm 1.82 \mathrm{a}$ & $1.6 \pm 0.48 \mathrm{a}$ & $2.5 \pm 0.98 \mathrm{a}$ & $0.87 \pm 0.2 \mathrm{ab}$ & $1.8 \pm 0.85 \mathrm{a}$ \\
& B & n. d. & $3.7 \pm 0.46 \mathrm{ab}$ & $1.8 \pm 0.81 \mathrm{a}$ & $1.4 \pm 0.37 \mathrm{a}$ & $0.75 \pm 0.4 \mathrm{ab}$ & $1.3 \pm 0.52 \mathrm{a}$ \\
& C & n. d. & $2.5 \pm 0.33 \mathrm{~b}$ & $1.1 \pm 0.43 \mathrm{a}$ & $2.1 \pm 0.40 \mathrm{a}$ & $1.08 \pm 0.33 \mathrm{a}$ & $1.3 \pm 0.46 \mathrm{a}$ \\
& D & n. d. & $3.0 \pm 1.9 \mathrm{ab}$ & $0.99 \pm 0.50 \mathrm{a}$ & $1.95 \pm 1.14 \mathrm{a}$ & $0.52 \pm 0.09 \mathrm{~b}$ & $1.71 \pm 0.19 \mathrm{a}$ \\
\hline
\end{tabular}

*Different letters in the same column and in the same metal $(\mathrm{Zn}, \mathrm{Pb}, \mathrm{Cu}$, or $\mathrm{Cd})$ indicate a significant difference at $\mathrm{p}<0.05$ according to the LSD test. n. d.: Not detect

\section{CONCLUSION}

Lechang $\mathrm{Pb} / \mathrm{Zn}$ mine tailings contained higher concentrations of $\mathrm{Pb}$ and $\mathrm{Zn}$ and lower contents of major nutrients. The combination of domestic refuse and inorganic fertilizer was more effective than inorganic fertilizer or domestic refuse alone in supporting plant growth on the tailings.

$V$. zizanioides had the highest tolerance to metal toxicities and accumulated the lowest concentrations of heavy metals in shoot among the three species tested. This species was considered more suitable for stabilizing mine tailings, and the danger of transferring toxic metals to grassing animals was minimal.

\section{ACKNOWLEDGMENTS}

The author would like to thank Ms. Zhou Mi for technical assistant. Financial support from the NSFC (No. 30100024), GDNSF (No. 990259), and the Research Grants Council of University Grants Committee of Hong Kong is gratefully acknowledged.

\section{REFERENCES}

Allen SE. 1989. Chemical Analysis of Ecological Materials, $2^{\text {nd }}$ ed. Blackwell Science Publishers, Oxford

Archer IM, Marshman NA, and Salomons W. 1988. Development of a revegetation programme for copper and sulphide-bearing mine waste in the humid tropic. In: Salomons W, Forstner U (eds.), Environmental management of solid waste, Overseas Typographers, Makati. 166-184

Baker AJM, McGrath SP, Sidoli CMD, et al. 1994. The possibility of in situ heavy metal decontamination of polluted soils using crops of metal-accumulating plants. Resour., Conserv. Recycl., 11: 41-49

Bradshaw AD, and Chadwick MJ. 1980. The Restoration of Land: The Ecology and Reclamation of Derelict and Degraded Land. University of California Press, Berkeley Los Angeles. pp.302

Bradshaw D. 1987. Recalmation of land and ecology of ecosystem. In: William, R.J., Gilpin, M.E., Aber, J.D. (Eds.), Restoration Ecology, Cambridge University Press, Cambridge. pp. 53-74

Evans DO, and Rotar PP. 1987. Sesbania in agriculture Boulder, CO: Westview Press

Friedland AJ. 1989. The movement of metals through soils and ecosystems. In: Shaw AJ (ed.), Heavy metal tolerance in plants: Evolutionary aspects. CRC Press, Inc, Boca Raton. 7-20

Ibekwe AM, Angle JS, Chaney RL, et al. 1995. Sewage sludge and heavy metal effects on nodulation nitrogen fixation of legumes. J. Environ. Qual., 24: 1199-1204

Jiang BL. 2000. Pollution ecology on leachate from municipal landfill, Ph. D. Thesis, Zhongshan University, China

Kantawanichkul S, Pilaila S, Tanapiyawanich W, et al. 1999. Wastewater treatment by tropical plants in vertical-flow constructed wetlands. Wat. Sci. Tech., 40: 173-178

Lan CY, Shu WS, and Wong MH. 1997. Revegetation of $\mathrm{Pb} / \mathrm{Zn}$ mine tailings: phytotoxicity of the tailings. pp. 119-130 in Wise, D. L. (ed.), Global environmental biotechnology, Elsevier Science, 
London

Lan CY, Shu WS, and Wong MH. 1998. Reclamaton of $\mathrm{Pb} / \mathrm{Zn}$ mine tailings at Shaoguan, Guangdong Province, PRC: the role of river sediment and domestic refuse. Biores. Technol., 65: 117-124

Liu AS. 1993. Soils in Guangdong Province. Science Press, Beijing, China. 325-339

Manguiat IJ, Sebiano AG, JAlolon AT, et al. 1987. Biofertizer and nitrogen fixation potential of Sesbania rostrata under flooded and nonflooded conditions as affected by inoculation and nitrogen application. J. Crop Sci., 12: 325

Ofori F, and Stern WR. 1987. Cereal-legume intercropping systems. Adv. Agron., 41: 41-90

Page AL, Miller RH, and Keeney DR. 1982. Methods of Soil Analysis, Part 2. Chemical and Microbiological Properties, $2^{\text {nd }}$ Ed. Agronomy, No. 9, ASA, SSSA, Madison, Wisconsin

Pichtel J, Kuroiwa K, and Sawyerr HT. 2000. Distribution of Pb, Cd and $\mathrm{Ba}$ in soils and plants of two contaminated sites. Environmental Pollution, 110: 171-178

Pichtel J, and Salt CA. 1998. Vetegative growth and trace metal accumulation on metalliferous wastes. J. Environ. Qual., 27: 618-642

Radziah O, and Shamsuddin H. 1990. Growth and Sesbania rostrata on different components on tin tailings. Pertanika, 13: 9-15

Sahi SV, Fasion V, Bryant NL, et al. Accumulation of heavy metals by Sesbania species. Proceedings of the $5^{\text {th }}$ International Conference on the Biogeochemistry of Trace Elements, Vienna. 582-583

Shu WS. 1997. Revegetation of Lead/Zinc Mine Tailings, Ph. D. thesis, Zhongshan University, China

Shu WS, Lan CY, and Zhang ZQ. 1997. Analysis of major constraints on plant colonization at Fankou $\mathrm{Pb} / \mathrm{Zn}$ Mine tailings. Chinese Journal of Applied Ecology, 8(3): 314-318

Shu WS, Xia HP, Zhang ZQ, et al. 2002. Growth and accumulation of heavy metals in four grasses grown on $\mathrm{Pb} / \mathrm{Zn}$ mine tailings at Lechang of Guangdong Province, China. Int. J. of Phytoremediation, 4: 47-57

Somasegaran P, and Hoben HJ. 1994. Handbook for Rhizobia: methods in legume-Rhizobium technology, Springer-Verlag, New York

Taylor MD, and Percival HJ. 2001. Cadmium in soil solutions from a transect of soils away from a fertilizer bin. Environmental Pollution, 113: 35-40

Tomekpe K, Dreyfus B, and Holsters M. 1996. Root nodulation of Sesbania rostrata suppresses stem nodulation by Sinorhizobium teranga but not Azorhizobium caulinodans. Can. J. Microbiol., 42: 187-190

Truong PN, and Baker D. 1996. Vetiver grass for the stabilization and rehabilitation of acid sulfate soils. Proc. Second National Conf. Acid Sulfate Soils, Coffs Harbour, Australia. 196-198

Vandermeer J. 1989. The ecology of intercropping. Cambridge University Press, Cambridge, UK

van Kessel C, and Hartley C. 2000. Agricultural management of grain legumes: has it led to an increase in nitrogen fixation. Field Crop Res. 65: 165-181

Wong MH, and Lau WM. 1985. The effects of applications of phosphate, lime, EDTA, refuse compost and pig manure on the $\mathrm{Pb}$ contents of crops. Agric. Wastes, 12: 61-75

Xia HP, and Shu WS. 2001. Resistance to and uptake of heavy metals by Vetiveria zizanioides and Paspalum notatum form lead/zinc mine tailings. Acta Ecologica Sinica, 21(7): 1121-1129

$\mathrm{Xu}$ LF, and Liu TH. 1996. The zonal differentiation of soil environmental background values and critical contents in Guangdong. Journal of South China agricultural University, 17(4): 58-62

Yang ZY, Yuan JG, Xin GR, et al. 1997. Germination, growth and nodulation of Sesbania rostrata grown in $\mathrm{Pb} / \mathrm{Zn}$ tailings. Environ. Manage., 21: 1-6

Yang ZY, Yuan JG, and Zhang HD. 1998. Growth, nodulation, N-fixing and seed production of Sesbania rostrata-Azorhizobium caulinodans symbiosis in South China. Journal of Applied Ecology, 9: 9195 
Ye ZH, Wong JWC, Wong MH, et al. 2000. Revegetation of $\mathrm{Pb} / \mathrm{Zn}$ mine tailings, Guangdong Province, China. Restoration Ecology, 8: 87-92

Ye ZH, Wong JWC, Wong MH, et al. 1999. Lime and pig manure as ameliorants for the revegetation on lead/zinc mine tailings: a greenhouse study. Biores. Technol., 69: 35-45

Ye ZH, Yang ZY, Chan GYS, et al. Growth response of Sesbania rostrata and S. cannabina to sludgeamended lead/zinc mine tailings: A greenhouse study. Environ. Inter., 26: 449-55

\section{A Brief Introduction to the First Author}

Bing Yang, as a doctorate student, is studying in School of Life Science, SunYat-Sen University, Guangdong, PRC. He has been engaged in using the Vetiver System for the purpose of mine tailings rehabilitation and wetland construction over 3 years and has 4 academic papers in these aspects published. 